\title{
Les Midinettes Révolutionnaires
}

\author{
The Activist Cinema Girl in 1920s Montmartre
}

\begin{abstract}
In their quest for official and cultural recognition, French First Wave critics such as Louis Delluc discursively positioned the working-class female cinemagoer as emblematic of the sorry state of unsophisticated French film audiences. From this discourse came the stereotype of the starry-eyed midinette, which is still used by French film critics to describe lowbrow film taste and an overly emotional mode of spectatorship. This essay attempts to reconstruct the social practice of cinemagoing among the midinettes of 1920s working-class Paris by focusing on the female fans of the serial Les deux gamines (1921). Both a critique of intellectual cinephilia as a cultural discourse and a geographically specific retrieval of the multiple ways in which socioeconomically and culturally marginalized audiences interacted with the cinema, this historical study repositions young women from working-class neighborhoods as key actors in film culture-fans, but also social activists. Through a study of disparate, unpublished archival material, including fan letters, film programs, and announcements in the leftist press, this essay attends to the social realities of a number of female film fans in Montmartre and grounds their spectatorship spatially within their local communities. KEYWORDS cinephilia, fandom, historical audiences, labor activism, Paris
\end{abstract}

Nevertheless certain movie theaters in the tenth arrondissement seem to me to be places particularly intended for me, as during the period when, with Jacques Vaché we would settle down to dinner in the orchestra of the former Théâtre des Folies-Dramatiques, opening cans, slicing bread, uncorking bottles, and talking in ordinary tones, as if around a table, to the great amazement of the spectators, who dared not say a word.

- ANdRÉ Breton, NADJA ${ }^{1}$

In writings such as "The Crowd" (I918), the French film critic and filmmaker Louis Delluc conjures a vision of Paris as a city without social borders, where bourgeois film lovers such as himself can drop into run-down local movie houses and breathe the same air as the local workers. ${ }^{2}$ Similarly, from André Breton's account above one imagines a city in which Surrealists rambled

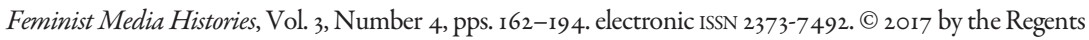
of the University of California. All rights reserved. Please direct all requests for permission to photocopy or reproduce article content through the University of California Press's Reprints and Permissions web page, http://www.ucpress.edu/journals.php?p=reprints. DOI: https://doi.org/I0.1525/fmh.2017.3.4.162. 
through the night, wandering from cinema to cinema in a dreamlike state. As romantic as they are, however, these stories do not tell us much about the historical conditions of cinemagoing in Paris following the Great War. What about the spectators surrounding these raucous men of the Parisian art world, ordinary people for whom cinemagoing was not an intellectual "provocation" but an essential part of daily life? What about the women-the majority of filmgoers in working-class arrondissements-whom critics such as Delluc so often disparaged in the columns of their own film journals?

It is astonishing that we know so little about what it meant for workingclass people to go to the cinema in 1920 s Paris. After all, Paris was the center for the ciné-club movement and the emergence of the French First Wave, and home to the famous Amis de Spartacus group's rebellious screenings of Battleship Potemkin (1925). And given the immense importance of the early cinephile critics-many of whom took pride in frequenting "ordinary" working-class cinemas-for our present-day understanding of the history and theory of film, it is surprising that so few scholars have ventured beyond cinephile accounts to investigate what such "ordinary" filmgoers themselves thought about film. Until now, class differences have largely been suppressed in cultural histories of Parisian cinemagoing.

Perhaps the reason we know so little about ordinary cinemagoers is because Paris was the birthplace of cinephilia, not despite it. In the early 1920 critics rallied around a new French cinema that we now call the French First Wave or Impressionist cinema, a movement that Richard Abel has termed the narrative avant-garde. ${ }^{4}$ Jennifer Wild deftly illustrates how "cinema's theatrical gentrification," which she ascribes in part to efforts by early cinephiles such as Ricciotto Canudo, alienated avant-garde figures like Breton and Vaché who sought the Dadaist pleasures of the "cinema of attractions." At the same time, however, the legitimation efforts of these cinephile critics to ennoble cinema as a true art form in the eyes of the French state and the bourgeoisie alike clearly sought to alienate another audience: the working-class spectator. These cinephiles may have paid close attention to the cinematic text, but they also theorized the ideal spectator of French film as essential for the elevation of cinema as a legitimate art form. They accomplished this largely by positioning themselves and their intellectual analyses in opposition to an imaginary spectator who combined several of the qualities they believed were keeping cinema from being recognized as the septieme art. Most important among these unwelcome qualities were working-class rowdiness and the supposedly immediate, overly emotional, and unreflexive attitude of female spectators in particular. 
The female film fan was one of the primary spectator "types" that emerged from the discursive reshuffling of spectator categories in the illustrated film weeklies of intellectual pretension. Much like her US counterpart, this female film fan avidly followed adventure serials, admired French, American, and Italian film stars, and dreamed of becoming a star herself. ${ }^{6}$ On the opposite end of the spectrum was the cinéphile, the intellectual and typically male connoisseur of film, who occupied the highest stratum in the discursive hierarchy of spectator groups. An example of the attempt to stratify audience members can be seen in this 1922 explanation by Pierre Henry, the young editor of Ciné pour tous: "Those who go to the cinema by chance and out of boredom, those who go first to see a certain star and then discover a love of cinema ... finally those who, pushing further their love for the cinema, begin to appreciate purely cinematographic value rather than the genre of film offered; these are the rare cinephiles."

Although these discerning cinephile spectators may have been "rare" in 1922 , their critical voices have become dominant in French film history by way of such historians as Christophe Gauthier. In La passion du cinéma, his comprehensive study of I920s Parisian cinephile culture, Gauthier describes the formation of a definitive opposition between the cinephile and the movie fan, with the latter most often characterized as a clueless young woman of a low social class who loves serials. ${ }^{8}$ This ordinary female movie fan is interesting because she became a discursive scapegoat for critics concerned with the poor state of French cinema in the early I920s. Cinephile critics wondered how they would ever convince an elite public to patronize cinemas when they were filled with women crying, sighing, and gasping at the twists and turns in a serial episode. For Delluc, Canudo, and many others, the young Frenchwoman attending the cinema came to represent all that the male, discerning cinephile was not. Even Jean Epstein instrumentalized the female movie fan as a marker of an uncritical, emotional mode of spectatorship. An example is this anecdote, which Epstein related to Cinéa readers in I921:

A young girl in the seat next to mine, unselfconscious in the darkness, hands clasped together under her chin, was participating fully in the on-screen drama. She let out surprised gasps and gestures. She herself was no more, in her place there was only the prairie, the bars, the stampedes, and a naive romance. Overcome by emotion she abruptly took off her hat and put it back on again. ${ }^{9}$

Here Epstein's subject is transformed from an empirical spectator to the concept of a viewer whom Christian Metz describes as "constantly in a sub-motor 
and hyper-perceptive state, a spectator at once alienated and happy ... a self filtered out into pure vision." 10

Perhaps the primary manifestation of the female movie fan was in the image of the midinette- a term that for Patricia Tilburg encompasses "milliners, dressmakers, flower makers, feather and fur workers, shopgirls, laundresses, poorly paid pieceworkers, or relatively well-paid seamstresses in the haute couture shops." 11 Through popular literature and song the midinette had entered the public imaginary by the early I9Ios as an important intersection of class and gender. ${ }^{12}$ The mid-nineteenth-century version of the modern midinette was Mimi Pinson, the bighearted but penniless seamstress of Alfred de Musset's nineteenth-century tale. ${ }^{13}$

From the I9ros, the term midinette took on a life of its own. During the Great War the growing visibility of women in the workplace led to a fascination with working women, who were often imagined as far more independent than their workload would have allowed, in particular if they had a family to care for at home. In his I9I2 study of Parisian workingwomen Octave Uzanne romantically described the petites midinettes:

Every morning they are to be seen streaming in from the populous and remote quarters of the city, clean, tidy, and even smart. Perhaps more than one has left a mother ill in bed, a father in the hospital, brothers and sisters more or less badly clothed and fed. But their youth and natural gaiety of spirits are proof against these troubles, and they go to the gilded cages where they are to be imprisoned and deprived of air, light, and horizon, chattering and singing like liberated birds. At midday the cage door is opened and out they fly gaily, to take their short and frugal meal in the cheapest and most promiscuous places. This sudden rush at midday has given them the name of midinettes. ${ }^{14}$

Not surprisingly, such idyllic portrayals of the midinette lent themselves well to France's burgeoning cinema culture, where she quickly became a central figure. This characteristically Parisian young woman appeared in many popular films, including Midinette (1909), Le Roman de la midinette (1914), Oscar et Kiki la midinette (1913), and most famously Midinettes (1917) with France's favorite star, Suzanne Grandais (fig. I). ${ }^{15}$ Blanche Montel played the quintessential midinette in Henri Desfontaines's Chichinette et Cie in 1921, and Dolly Davis played a seamstress in René Hervil's 1924 film Paris, with Cinémagazine describing her character as "in a word, . . Parisienne, the Parisienne of Montmartre, the Parisienne of rue de la Paix, all it takes to lead her astray is a bouquet of flowers, but the slightest hint of dishonorable behavior will bring 


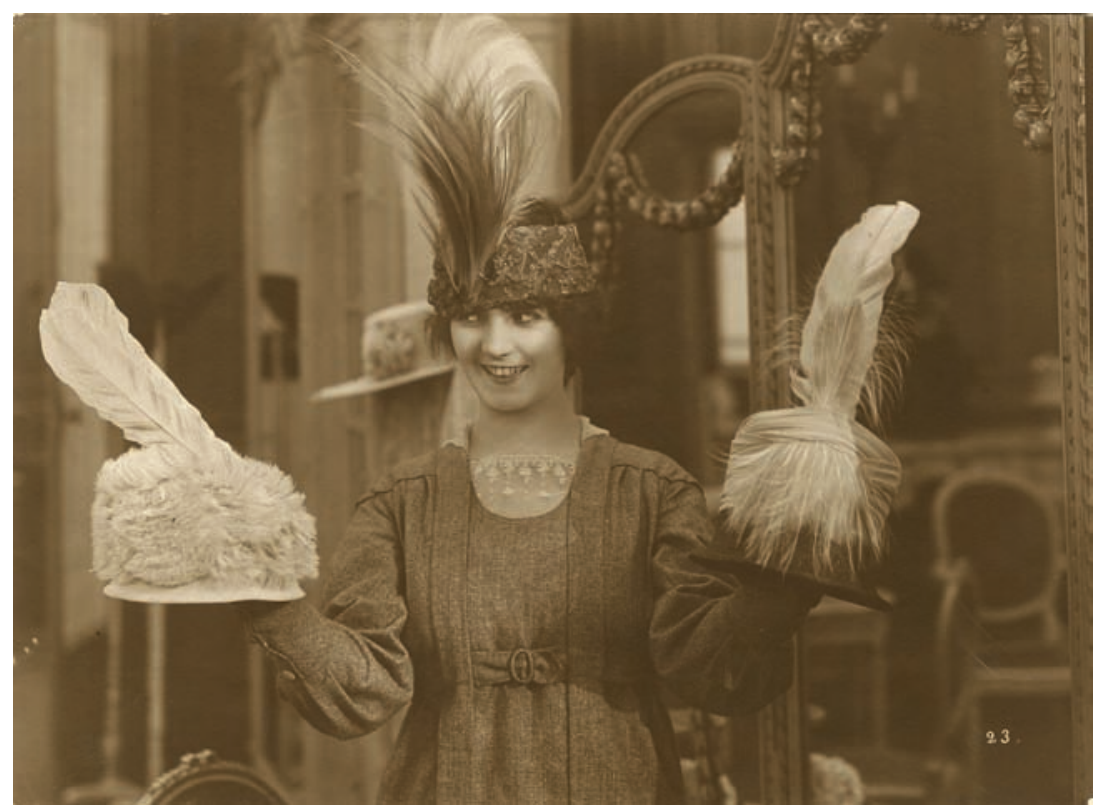

FIGURE 1. Production still for Midinettes (dir. René Hervil, Louis Mercanton), I917, showing Suzanne Grandais. Courtesy Cinémathèque française.

her back to her mother's side." ${ }^{16}$ Fan magazines would often find their way into the hands and onto the bedroom walls of the midinettes in these films; in the film Paris, for example, a midinette is seen holding a copy of Cinémagazine, and in La fermme nue (1926) we see pages from Mon Ciné pinned to the bedroom wall of the dress model played by Louise Lagrange. ${ }^{17}$

As early as the mid-I9Ios, such working-class female fans were stigmatized in the emerging film press as "primitive" spectators emblematic of a prewar type of "primitive" cinema. Early cinephiles fixated on the midinette as symbolizing an excessive lowbrow taste for serials and stars. Since then, the midinette has served the role of cinephilia's "other," emerging again and again to reassure intellectual critics of their superior taste. Discussing the French cinema magazine $L ' E$ Eran français of the 1950s, Geneviève Sellier problematizes the category of the midinette, which she describes as "an adolescent or young adult from a working-class background, who develops a fannish curiosity for her favorite stars, who can be male or female, often confusing the characters they play on the screen with the real life actor or actress." ${ }^{18}$ Sellier critiques the opposition between, on the one hand, "the 'bad' position of the fan or the midinette," and on the other hand 
"the 'good' position of the enlightened cinephile." ${ }^{\text {"19 }}$ She also shows that this divide is explicitly gendered, separating the female working-class fan readership from the cultivated readership of male cinephiles. ${ }^{20}$

Even today French film critics continue to use the term midinette to designate the opposite of the cinephile in serious film magazines like Positif and Cabiers du cinéma. For example, in Pierre Eisenreich's review of the 2013 sci-fi romance The Host, he complains, "Every five scenes you get the teenage kiss to thrill the audience supposedly made up of midinettes." ${ }^{\text {21 }}$ According to another Positif critic, Eithne O’Neill, in Sliding Doors (1998) Gwyneth Paltrow's “profile of a fashion victim with 'Lady Di' syndrome targets midinettes." 22 Similarly, in his 1993 review of a French cinema encyclopedia, Yann Tobin adopts a thoroughly 1920 expression when he writes, "It isn't easy to please the cinephile and the midinette at the same time." ${ }^{23}$ Describing a publication on the actor Gérard Depardieu in 1986, Michel Sineux writes that the star biography has "midinette connotations," and adds, "That isn't a compliment." ${ }^{24}$

Despite the persistence of such clichés in cinephile criticism, historians' selective editing and translation of early film theory texts and critical writings that focus mainly on the filmic object have erased the centrality that the divide between highbrow and lowbrow audiences had in early discussions of cinephilia. Canudo and Delluc's conservative and elitist views of the Parisian working-class audience are largely absent from edited English-language volumes, and are found only in primary source materials like the illustrated film press and newspapers. This essay therefore balances cinephile critics' descriptions of the working-class female fan against primary sources revealing how she saw herself. By this I do not mean to generalize a generation of young working-class women attending the cinema in 1920 Paris or to recover a specific mentalité. My aim is rather the opposite. Through a study of disparate, unpublished archival material, including fan letters, film programs, and announcements in the leftist press, I attend to the social realities of a number of these fans, and, with the help of geographical data contained in the materials, ground their spectatorship spatially within their local communities. This micro-archival approach allows the historian of cinema spectatorship to re-embed cinemas within their social context. Much as Robert C. Allen argues that rural moviegoing in the American South should be understood as a valid contribution to American film history, so does this essay respond to James Hay's call to consider "how social relations are spatially organized ... and how film is practiced from and across particular sites and always in relation to other sites. In this respect, cinema is not seen in a dichotomous relation with the social, but as dispersed within an environment 
of sites that defines (in spatial terms) the meanings, uses, and place of 'the cinematic."' 25

My approach involves a fundamental decentering of the city's film culture, shifting from narrow concerns of an intellectual elite to the concrete concerns, interests, and pleasures of working-class women in a time of interwar social crisis. Parisian high society and the cinephile public had in common a disdain of the faubourg cinemas that were attended by working-class audiences. ${ }^{26}$ In order to redress the resulting historiographical imbalance, I turn to cinemas in one of the most ethnically diverse, working-class, and vibrant communities in Paris: the eighteenth arrondissement. If the working-class film fan was at the bottom of the hierarchy of spectators, then the multifunctional neighborhood cinemas at the northern edge of the city were on the lowest rung of the Parisian exhibition ladder. I draw upon a collection of one hundred fan letters written to serial star Sandra Milowanoff in 1921, the year of her first success in Les deux gamines (I921). ${ }^{27}$

By focusing on the fan letters sent from young Montmartre women to Milowanoff and situating them in conversation with notices in the leftist press, this essay reveals heterogeneous and localized modes of film engagement in the eighteenth arrondissement. Using Milowanoffs letters as insights into the experience of individual cinemagoers, I reconstruct their spatial and sociocultural context in order to account for the roles cinema played in the everyday lives and aspirations of the midinette. By thus moving beyond histories of the emergence of cinephilia to explore the female spectator's own experience of Parisian cinema culture, my approach draws on the exemplary work of feminist film historians such as Jennifer Bean, Antonia Lant, and Shelley Stamp, who shed light on women's active role in the creation of film culture without thereby dis-embedding them from the historical conditions that shaped their concerns and constrained their range of action. ${ }^{28}$

The interconnections between the working-class identities of these young women and their cinema practices become all the more apparent in the context of 1920 Paris, where trade unions, consumer leagues, and the Socialist and Communist Parties regularly used cinemas for political meetings, lectures, fund-raisers, and strike actions. One reader of Ciné pour tous, a fan of Pearl White serials and of Douglas Fairbanks, used the pseudonym Mimi Pinson in her correspondence with the magazine, as did a reader of Cinémagazine. ${ }^{29}$ Cinema fans' use of the pseudonyms Mimi Pinson, petite midinette, midinette, but also Jenny l'Ouvrière (a seamstress from literature and popular song), typist (dactylo), and stenographer (sténo), demonstrates the centrality of class identity 
to their cinemagoing. ${ }^{30}$ For many communities a cinema's local, political, national, or ethnic identity was central to securing successful negotiations for increased rights as workers, veterans, housewives, and citizens. Cinemas, therefore, were spaces of new opportunities and possibilities; in a very real sense they offered the chance of a brighter future for young workers, whether this be through collective political activism or collective fan letter writing.

By 1918 the annual profits of cinemas had skyrocketed, as had the number of cinemas. Exhibitors had labor unions in part to thank for this sudden increase in attendance. The General Confederation of Labor and Socialist municipal councillors succeeded in securing an eight-hour workday in April 1919, a victory that was to some extent won through mass meetings in Parisian cinemas. Once a certain measure of leisure time was secured, a circular process of self-reinforcement emerged as workers transformed cinemas into spaces not only for leisure but also spaces to fight for leisure as well as for a range of other demands. On May Day 1919, for example, three mass meetings called by the Socialist Party were held at the Cinéma Stephenson, Cinéma Ornano, and Cinéma Lamarck in the eighteenth arrondissement (fig. 2). ${ }^{31}$ In direct response to this new audience, exhibitors sought to profit by building cinemas in working-class neighborhoods of Paris where men and women could spend their so-called "eight hours of play."

By seamlessly transitioning from reading fan magazines, watching films, writing fan letters to their favorite stars, collecting postcards and star signatures, and participating in local beauty contests to political organization in their local cinemas, these fan-activists participated in a cinema culture that is alien to the cinephile culture originally created through the labors of critics such as Delluc. To understand I920s faubourg cinemagoing on its own terms, film spectatorship in its widest sense should not be seen as distinct from working-class women's role as underpaid and overworked department store employees, seamstresses, and stenographers who met in cinemas, in part, to improve their lot. To separate these two kinds of cinema-centered activity as fitting into the categories of, on the one hand, leisure, and on the other, professional or political life, would be to retrospectively apply today's conception of cinema as an autonomous sphere, disentangled from the spectators' everyday realities. Cinema was intrinsically embedded in the life of working-class people, and it was only through the efforts of early film critics such as Delluc, critics who advocated an elite appreciation of art cinema, that this embeddedness was overcome and forgotten.

In the following, I first turn to Delluc and his fellow cinephile critics to show how they articulated their intellectual anxieties concerning popular film culture 


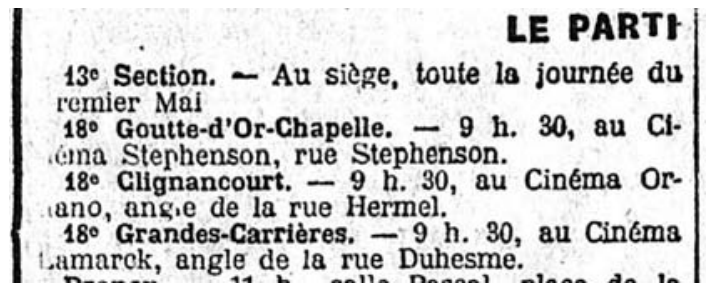

figure 2. Notice in Le Populaire, May I, I919, of

Socialist Party meetings in cinemas. Bibliothèque

Nationale de France.

as a cultural hierarchy in which the overexcitable, passive, and romantic midinette came to represent all that stood in the way of true cinema connoisseurship. I then turn to the more important task of reconstructing the cinema-centered lifeworld of a number of these working-class women to demonstrate how the full range of their daily activities, from starry-eyed identification with film actresses to self-conscious political activism, constituted their local cinemas as central sites in the social fabric of faubourg life.

\section{THE CINEPHILE RECEPTION OF LES DEUX GAMINES}

The ubiquity of the midinette figure in the texts of critics such as Epstein, Delluc, and Canudo made it difficult for contemporary female spectators to escape its negative connotations. Their attempts at taking part in highbrow film discourse were often rejected as inappropriate or comically amateurish and overreaching. This is most obvious in Delluc's scolding of those female readers of Cinéa who expressed their love for popular serials such as Les deux gamines.

While much scholarly attention has been paid to Louis Feuillade's prewar crime adventure serials Fantômas (1913-14), Les Vampires (1915-16), and Judex (I916), his postwar serial melodramas starring Sandra Milowanoff have been left in comparative critical silence. ${ }^{32}$ In addition to Milowanoff, Les deux gamines, Feuillade's grand film en série released on January 28, I921, starred Georges Biscot, Olinda Mano, and other favorites from the Gaumont troupe. ${ }^{33}$ The twelve episodes of Les deux gamines, which appeared concurrently in the daily newspaper L'Intransigeant, trace the story of Ginette (Milowanoff) and Gaby (Mano), daughters of actress Lisette Fleury (Violette Jyl), who has the ill luck to be married to the alcoholic criminal Pierre Manin (Fernand Herrmann) (figs. 3,4$).^{34}$

In the first episode we find the operetta star regretfully leaving her daughters in Paris under the care of their godfather, Chambertin (Biscot), and taking 


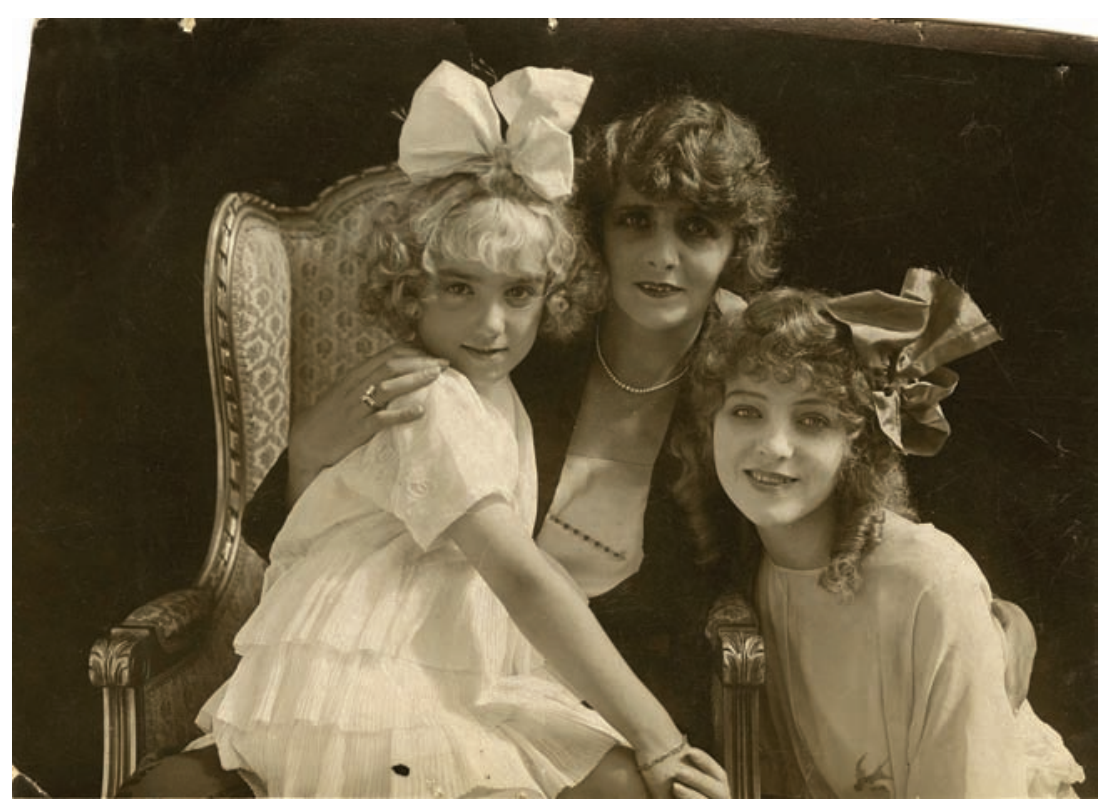

FIGURE 3. Production still for Les deux gamines (dir. Louis Feuillade), I921, showing Sandra Milowanoff, Olinda Mano, and Violette Jyl. Courtesy Cinémathèque française.

the boat to America to tour the country. Chambertin-also a music hall performer-accompanies the daughters to a convent, where the girls test the patience of the nuns before a tragic note hits when they learn that their mother's ship has sunk and she has surely drowned. Ginette then becomes the main protagonist, and the serial follows her trials and tribulations as she escapes death from a cliff fall, reunites with her escaped-convict father, is tracked by the police as an accomplice, gets kidnapped by a criminal gang, and finally reunites with her mother and gets engaged to her gentleman savior (Édouard Mathé) in the final episode.

Les deux gamines became the highest box office earner to date for the Gaumont company. The first episode screened in thirty-nine Parisian cinemas in its first week, and by the end of February I92I the audiences of sixty-nine Parisian cinemas were following the serial. As a special attraction, Milowanoff and Mano performed "in flesh and blood" on stage at the Idéal Cinéma at Io० ave de Saint-Ouen, a cinema described by manager Georges Parisot as "a modest cinema in an extremely working-class neighborhood." ${ }^{35}$ Milowanoffs fans were also discursively situated as working class, anchored to the faubourg areas of Paris. 


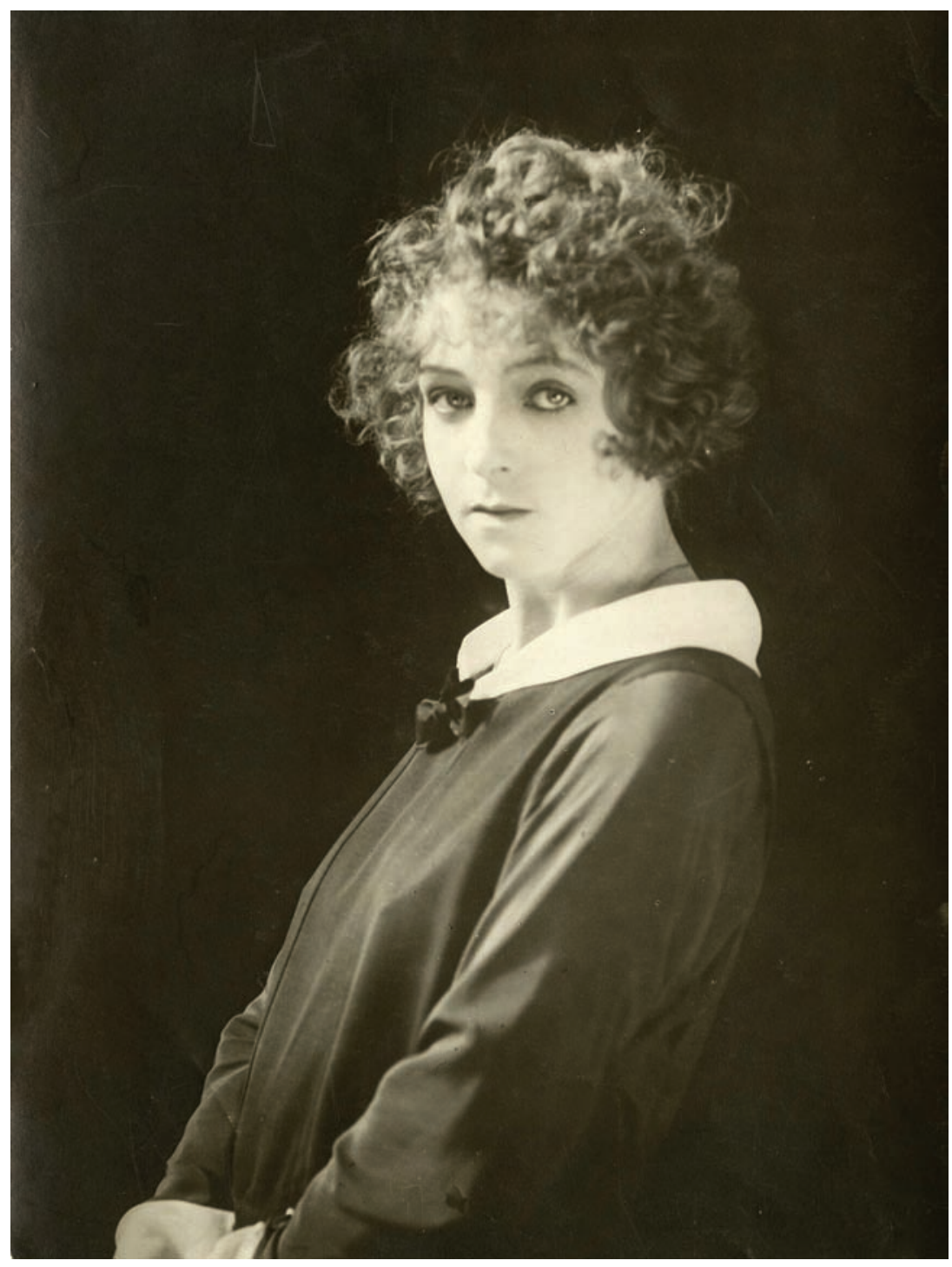

FIGURE 4. Publicity image for Les deux gamines (dir. Louis Feuillade), I92I, showing Sandra Milowanoff. Courtesy Cinémathèque française.

Mon Ciné journalist Jean Frick describes Milowanoffs popularity in the following terms: "You have to have heard the 'Ah!' sighed in unison by a whole Sunday afternoon audience in a faubourg cinema when Sandra Milowanoffs face appears on the screen to realize the popularity of this young artist." ${ }^{36}$ 
When asked to illustrate cinema's potential as a universal language, Marcel L'Herbier responded that Les deux gamines, although an enormous success, did not fulfill the requirement to please all three categories of spectators: the "vulgar," the "average," and the "elite." He went on to state, "Nothing in [the film] comes close to pure cinema. [It] fatally disappoints somebody, whether from above or below. Heaven is off-limits to [it]." ${ }^{\text {37 }}$

Cinephile heaven may have been off-limits to Feuillade's serial, but such elitist opinions didn't affect Milowanoffs huge popularity as Ginette. Her success can be explained in part by the timing of the release. When the writer Marguerite Bourcet looked back in 1936 on the post-Armistice popularity of the melodramatic adventure serial, she wrote:

It seemed that after those four awful years, people were tormented by a profound need for purity, for sentimentality, for naïveté. Not only did American films send us high-quality ingenues, but France, too, followed the fashion. Over those long weeks, hundreds of thousands of spectators followed the adventures of Les deux gamines and L'Orpheline [1921] incarnated by the blonde Sandra Milowanoff. And even grown adults cried with an authentic pleasure at these stories worthy of La Semaine de Suzette [a magazine for young girls]..$^{38}$

Reflecting on the dearth of such popular films in Robert Brasillach and Maurice Bardèche's 1935 publication Histoire du cinéma, Bourcet felt that lowbrow serials should have their place in film history precisely because of their popularity with the French public, meaning, "They must have possessed at least a fragment of their aspirations, their tastes, and their dreams." ${ }^{39}$ Yet in contrast to the popular appeal of Les deux gamines during its twelve-week run, contemporaneous film critics saw little to admire in it. Delluc was very vocal about his disappointment in Feuillade's career choices. In July 1919, two years before the release of Les deux gamines, he wrote:

I might say that Judex [1916], La Nouvelle mission de Judex [1917], Vendémiaire [1918], and Tih Minh [1918] are more serious crimes than those of authors who have been condemned by the War Council. Spectators in their thousands moan with pleasure like the people of Thebus holding out their arms to Oedipus so that he might save them from the plague. Oedipus didn't hear them very well. Evidently Feuillade has not committed the eccentric acts of the young Oedipus, nor does he deserve his punishment, and we will not gouge out his eyes. But one can still be blind without having had one's eyes gouged out. ${ }^{40}$ 
Although Delluc conceded that Judex was "technically superior to any other French production at the time," he felt angry that despite having the "talents, means, and confidence" to do "great things," Feuillade persisted with serial melodramas, which Delluc thought was "artistic suicide." ${ }^{41}$ In summarizing the year's films at the beginning of the new film season in 1921, Delluc wrote of Les deux gamines, "Louis Feuillade takes technical care with his serials. All that is left to do now is give them more interesting characters and subjects. That will please everyone. But may the devil take me if he listens to a word I say!" ${ }^{2}$

Such highbrow criticism may seem unnecessarily condescending from our vantage point, but nevertheless it had a profound impact on the historiography of French cinema. The sparse critical attention given to Feuillade's serials made between the end of the war and his death in 1924 is due in part to our reliance on cinephile criticism, one consequence of which was that successive film critics and historians simply omitted popular serials from the historical trajectory of French cinema. Thus Brasillach and Bardèche's I935 volume, which according to David Bordwell "codifies central tendencies of the Standard Version [of stylistic history]," saw the period between 1919 and 1923 as characterized by the evolution of cinema as an art form. ${ }^{43}$ In this evolution, the melodramatic serials that Parisian working-class audiences flocked to see week after week had no place.

Similarly, the female spectators who followed Les deux gamines were stigmatized for their lowbrow taste when they wrote to Delluc's Cinéa to voice their thoughts and preferences. When one reader wrote to say that she preferred watching Les deux gamines and Près des cimes (1921) over Swedish films, she received the following sarcastic reprimand from Delluc: "Bravo, Miss, the barrière public will agree with you. ${ }^{\prime 4}$ Again, the female spectator is associated with a peripheral space of the city, this time to the barrière, the working-class neighborhoods bordering the city, areas marred by the wastelands that were previously the city's fortifications.

Delluc was not alone in his discursive construction of film taste along class and gender lines. In his review of the week's press screenings in Scénario in late 1920, Pierre Veber wrote, "We have a quantity of popular films made up of naive emotion: Les deux gamines and Fille du peuple [1920]. There is a public for this type of drama, the public that used to frequent the Boulevard du Crime." ${ }^{\text {45 }}$ The editor of Ciné pour tous, Pierre Henry, clarified for Milowanoff fans their unimportance and unworthiness in the public sphere of film culture when he wrote, "The fact that one loves Léon Mathot or Sandra Milowanoff does not in the least mean that one loves the cinema. No more than loving cathedrals 
indicates a true religious belief." ${ }^{\$ 6}$ In a similar public purging act, Henry made clear that following Feuillade's ciné-romans was not behavior he would tolerate from Ciné pour tous readers. His feelings about the Gaumont actress are revealed in the following jibe: "Sandra Milowanoff: Les deux gamines . . other silly ciné-romans are on the horizon; oh! Sorry, I didn't know you liked them." ${ }^{47}$

Thus, from the first year of her acting career, Milowanoff was placed in the category of lowbrow, non-cinephile film. And just as Feuillade was placed on the opposite spectrum of the avant-garde filmmaker Marcel L'Herbier, so was the female Milowanoff fan placed on the opposite end of the spectrum to that of the male cinephile spectator or intellectual film critic. ${ }^{48}$ By the end of the I920s, the image of the nonintellectual, uncritical female spectator was discursively set. In 1929, for example, the twenty-two-year-old future screenwriter Roger Vailland wrote a revealingly mocking homage to his spectatrice idéale (ideal female spectator). Vailland describes how upon meeting him, she "wished to go to the cinema and was flicking through the programs. I watched her do it. She didn't care about the nationality of a film. Even the name of the filmmaker held no interest for her. She was unable to decide between different stars." $\mathrm{He}$ comes to the conclusion that

the spectatrice idéale is exactly the opposite of the critic. The latter considers a film as an oeuvre, a unit. He concerns himself with the question of whether the film has a rhythm, if it expresses what it seeks to express and only what it seeks to express, if the lighting is well regulated, if there is a careful mise-enscène, whether the photography is good. For the spectatrice idéale, a film is something like the optimistic dreams she has just before falling asleep at night, or when walking down the street after meeting a handsome manonly better... To enter into the universe of the cinema she must follow the usherette's trembling lamp and sit down in the shadows, next to other unknown worshippers. What a sadness it would be to the spectatrice idéale if one day the lights went on inside the cinema. ${ }^{49}$

Vailland's distinction between himself and his female friend expresses the opposing spectatorial positions of the male, critical cinephile and the starry-eyed female movie fan that is now fixed in French film journalism and in the popular imaginary. In order to discursively position himself as a true cinephile, Vailland draws upon the familiar paradigm of the starry-eyed woman with no idea of cinema's artistic status. Delving into alternative archival material is crucial if we are to mend the lacuna in French film histories like that of Brasillach and Bardèche, a lacuna caused by heavy criticism of Feuillade's serial by critics striving for the development of cinema as an art form and the improvement of 
cinema audiences. Rather than taking such discursive categories at face value, the film historian must work to undo the damage caused when, in Antonia Lant's words, "women's reflections remain dispersed and unremembered, veiled by historical opinions formed through the texts of men." ${ }^{50}$ In what follows I hope to complicate Vailland's gendered paradigm by exploring the potential for the midinette movie fan to be a politically active spectator in working-class cinemas of Montmartre.

\section{THE FEMALE FANS OF MONTMARTRE}

The release of Les deux gamines coincided with the postwar emergence of the illustrated film weeklies, which provided the mailing addresses of cinema celebrities, thus triggering a new cultural phenomenon: fan correspondence with the stars. $^{51}$ The first issue of Cinémagazine appeared in Paris bookshops and train station newsstands on January 2I, I92I, just a week before spectators flocked to catch the first episode of Les deux gamines on January 28. This was a happy coincidence for fans of the serial, for Cinémagazine readers were enraptured to find in its subsequent issues the address of Sandra Milowanoff. More importantly, they learned that they could write to the young actress and expect a personal letter, or even a signed photograph, in return (fig. 5). In October I92I, Guillaume Danvers, the editor of Cinémagazine, recalled the impact made by Milowanoff with her first film serial:

I remember the avalanche of letters that we received at the editorial board of Cinémagazine when Les deux gamines appeared in cinemas. What is the real name of Ginette? .. . How old is she? ... Is this her first film? ... Does she wish to be married? And all of her admirers-it's astonishing that cinegraphic artists have admirers!- - learned that the adolescent Ginette was married and ... a mother! .. . Ginette a mother! ... It could almost be the title of a film in which she could act delightfully with her baby and her young husband. ${ }^{52}$

Indeed, the letter columns of the illustrated film press were ripe with readers seeking information about Milowanoff and the other cast members of Les deux gamines. Cinémagazine published Milowanoffs address the day the sixth episode was shown in cinemas, and Ciné pour tous published it the day of the second episode's release with the note, "Sandra Milovanoff $[s i c]$ is really called Mme de Meck. You can write to her at Studios Gaumont, 53, rue de la Villette, Paris." ${ }^{53}$ The star's studio address was again published in Ciné pour tous in April and May of 1921. 


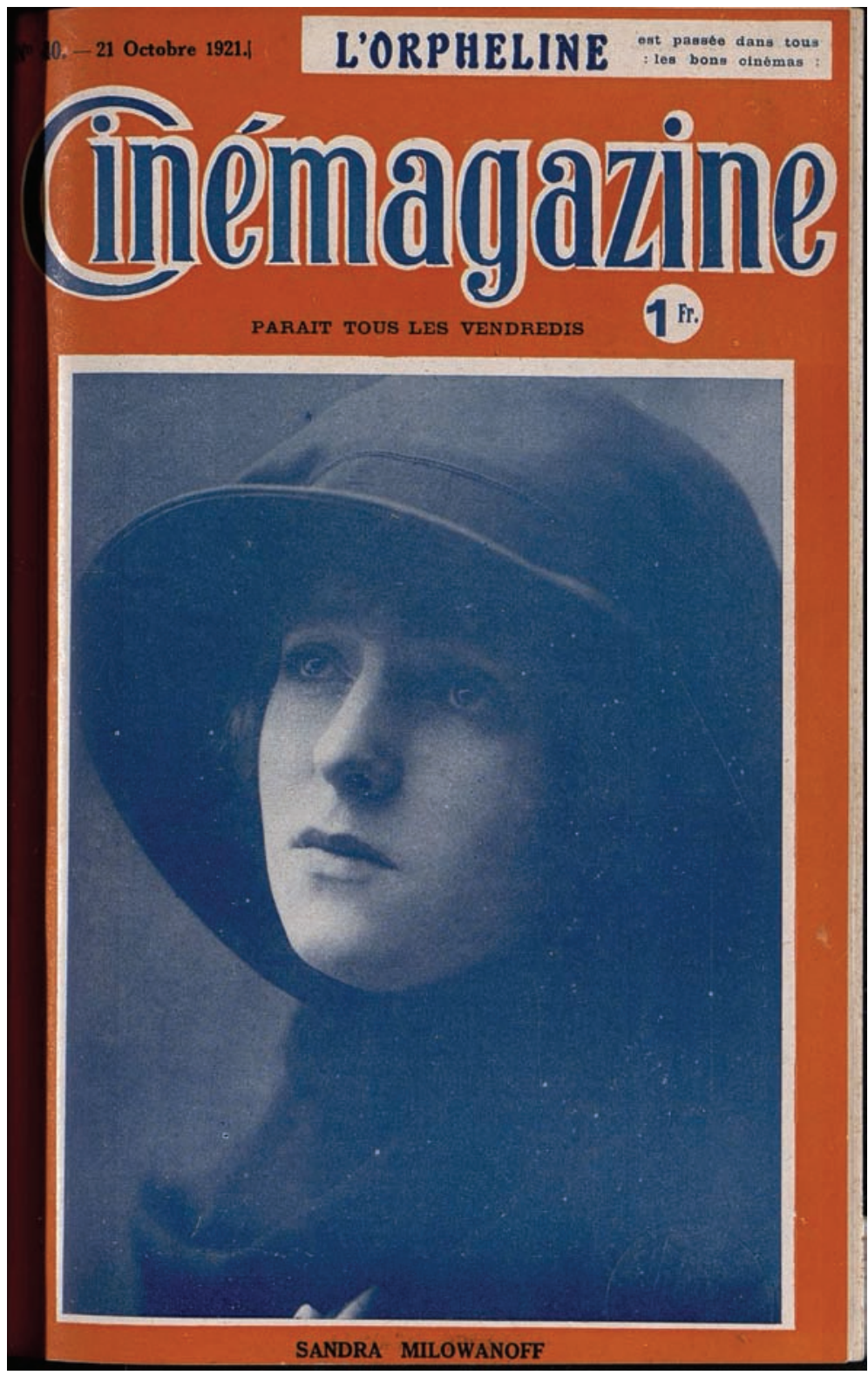

FIGURE 5. Sandra Milowanoff on the cover of Cinémagazine, October 2I, I92I. Courtesy Cinémathèque française. 


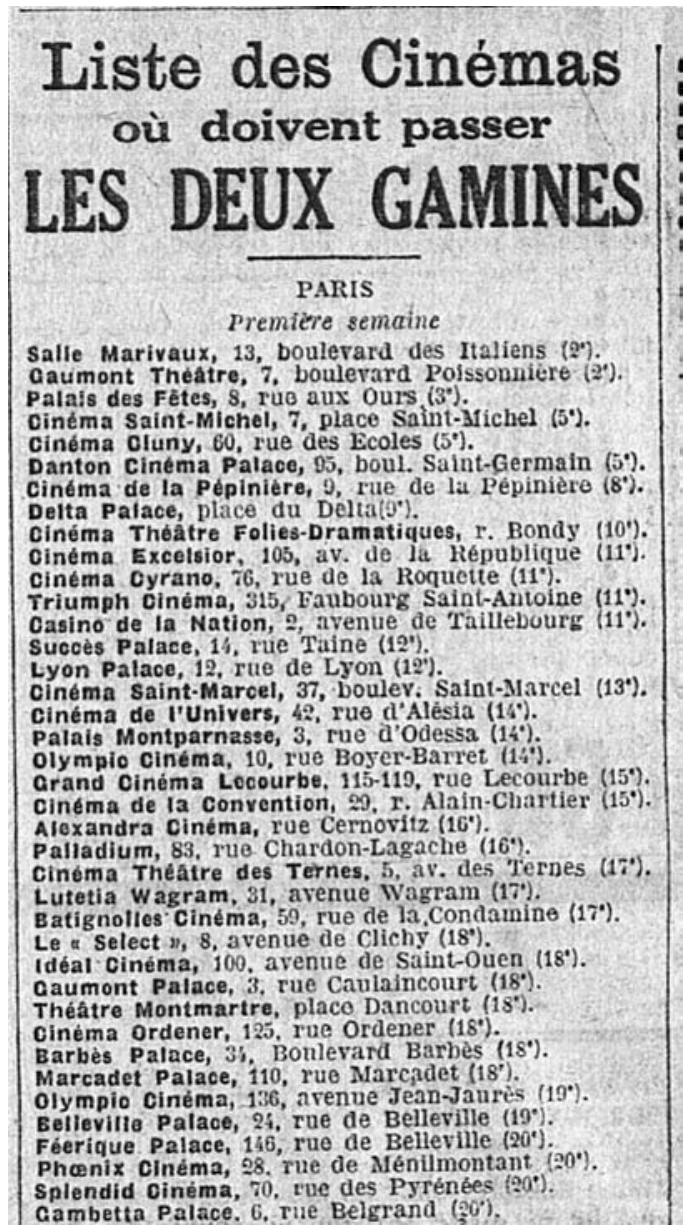

FIGURE 6. Show listings for Les deux gamines (dir.

Louis Feuillade), I921, in L'Intransigeant, January 28, I92I. Bibliothèque Nationale de France.

Milowanoff fans living in the eighteenth arrondissement were able to follow Les deux gamines at nine different cinemas (fig. 6). ${ }^{54}$ Narrowing our focus to this area proves useful for several reasons. First, by attending to the spatial organization of cinemas one can better understand the intersections of film culture with community activism. The barrier between work and leisure was fluid in the many cinemas that were strategically used by unions and consumer leagues because of their practical proximity to work or the marketplace. Second, the eighteenth arrondissement had the highest concentration of cinemas in Paris, 
each with its own distinct programming trends. ${ }^{55}$ For example, in 1921 Montmartre cinemas used live variety performances in their programs more than anywhere else in the city. ${ }^{56}$ Third, the eighteenth arrondissement was hugely diverse in terms of its population. According to the census of I92I, Montmartre-together with the eleventh arrondissement-had the highest number of immigrants, with 17,463 non-French residents. ${ }^{57}$ This was also one of the densest areas of the city, with 600 to 800 inhabitants per hectare. ${ }^{58}$ Postwar inflation and widespread evictions made Montmartre extremely politically active, and the Socialist and Communist Parties made it their stronghold along with other prominent activist groups like tenants' and consumers' associations. Factories also surrounded the area, in Batignolles to the west, outside the city limits to the north, and in La Chapelle to the east, where gas plants stood back-to-back with the refineries further to the east in La Villette. Sociological maps of the city described the area as a quartier ouvrier, a workers' neighborhood. ${ }^{59}$ Surrounding the Gare du Nord train station lived many public service workers in the electricity, post, gas, and public transport sectors. ${ }^{60}$ Furthermore, the area was brimming with midinettes, since garment workers primarily lived in Batignolles and Montmartre, close to the fashion houses. ${ }^{61}$

Despite characterizations of the midinette as a passive, uncritical spectatorconsumer by cinephiles such as Vailland, the fan letters reveal her fandom to be an active, participatory practice. Whereas the cinephile criticism of the $1920 \mathrm{~s}$ was addressed to a national, elite audience interested in aesthetic analysis and formal experimentation, these ordinary filmgoers' experience of cinema was spatially close, embedded in the individual and collective concerns of the neighborhood and its culture of survival and entertainment. The "thick description" I aim at here therefore eschews formal analysis in favor of a bottom-up rendition of the local, intimate, and material dimension of cinemagoing as a social practice. $^{62}$

Taking this historical study to a micro-archival level similarly repositions women as key actors in film culture, as fans but also as social activists in the same cinemas where they could follow their favorite serials. The effacement of barriers between work and leisure in the cinema space extends logically into a rethinking of fan letter writing as a form of production, a cultural practice that goes beyond mere passive spectatorship and blends in with other forms of collective action such as union meetings, community decision-making, and voting. Letter writing signifies a resistant activity insofar as many fans use their workplace as the return address for correspondence, invite the star to their place of work, and ask her for advice on how to become an actress, signifying a wish for 
social advancement and an overturning of the roles of production and consumption. Fan letter writing even opened up a utopic space of exchangeability when fans sent their photographs to Milowanoff in exchange for possessing her star image. My archival method therefore aims to reconstruct the "indeterminate trajectories" of the itinerant spectators who, consciously or unconsciously, refused to conform to the expectations of intellectual film critics and their industry allies. ${ }^{63}$

Milowanoff corresponded with nine different groups of young women in I921, and five of these epistolary friendship groups lived in Montmartre or just outside the limits of the eighteenth arrondissement. In the cluster of commercial activity surrounding the eighteenth arrondissement town hall and the area where the four quartiers joined together lived several Milowanoff fans who are representative of the many young women who wrote to the actress. ${ }^{64}$

One, Fernande Courtois, wrote to Milowanoff on March 8, 1921, the week that the sixth episode was screened (fig. 7). Courtois was most likely following the serial at the Nouveau Cinéma Ordener, a little more than one hundred meters from her apartment building. According to historian Jean-Jacques Meusy, this nine-hundred-seat neighborhood cinema opened in I9II and had a "familial public of workers and petit bourgeois." ${ }^{165}$ Like many of the girls, Courtois situated herself in terms of her profession, describing herself as a petite midinette. Her letter hints at the central role cinema played in her scarce leisure time:

Madame,

Please forgive my audaciousness in writing you this little note. But I admire you so much every Saturday in Les deux gamines that I could no longer keep myself from letting you know my admiration. Dear Madame, I will push my audacity so far as to ask you to be kind enough to send me one of your photos that I will be very happy to hang up in my little bedroom. I end with the hope that you will not refuse this happiness to a little midinette.

Sincerely, your little admirer,

Fernande Courtois ${ }^{66}$

Courtois was able to follow her favorite star so assiduously thanks to the industrial actions carried out by fellow midinettes in the previous five years. As Nancy L. Green notes, the 1917 law for the semaine anglaise (Saturday afternoon off) and the 1919 law granting the eight-hour workday were only passed thanks to strikes by midinettes (fig. 8) ${ }^{67}$ It is possible that Courtois belonged to the Syndicat de l'Habillement, the union of garment workers responsible for these gains. ${ }^{68}$ This 


\section{Pares tat 3 2 21}

(4) Hacame:

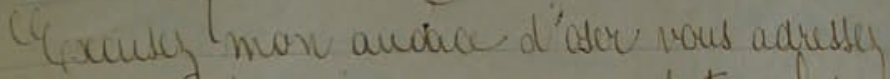

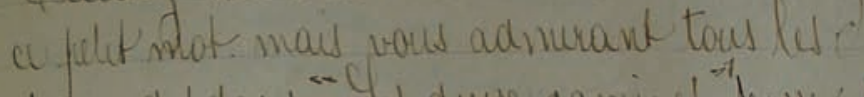

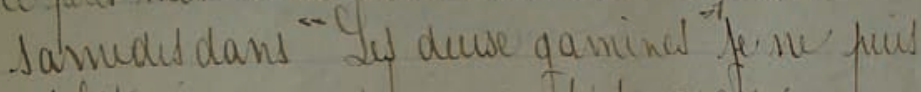

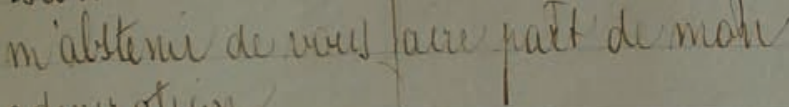
adsucutuor

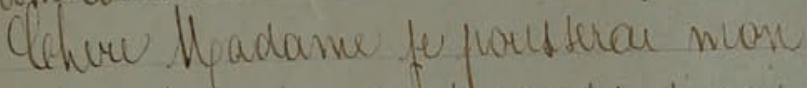
quedace lusque ares demander davour

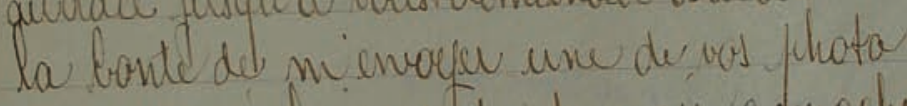

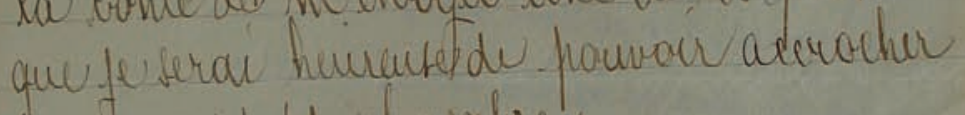

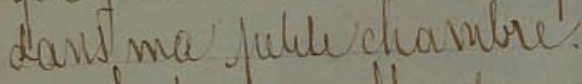

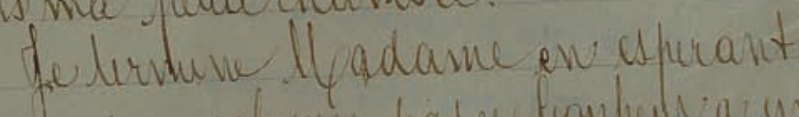

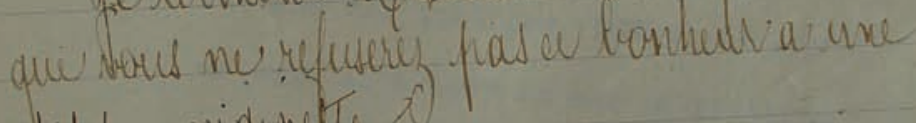
helule midund of

Gowaternetit a vail

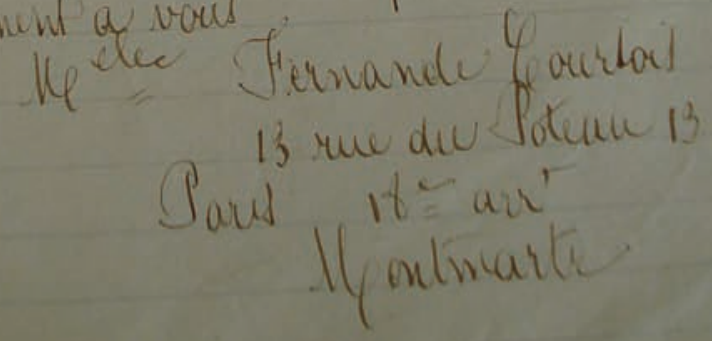

FIGURE 7. Letter to Sandra Milowanoff from the midinette Fernande Courtois, Paris, March 8, I92I. Cinémathèque française, Collection Jaune. 


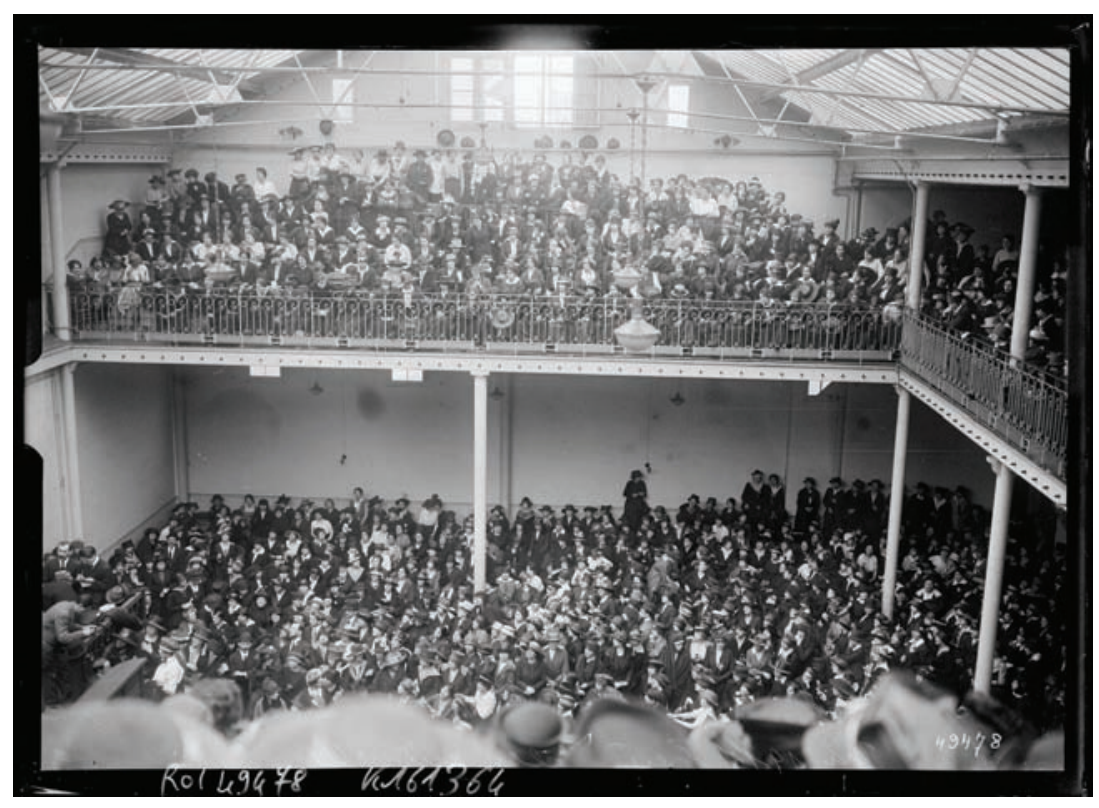

FIGURE 8. Press photograph of the 1917 Midinettes' Strike. Agence Rol, 1917, Bibliothèque Nationale de France.

union embraced cinema more wholeheartedly than any other union both by integrating films into its political activities and by using Parisian cinemas for political meetings. ${ }^{69}$ For the 1921 Christmas celebrations the union organized a party at the Salle Japy with a film program provided by the Bon Cinéma, a Montmartre-based leftist exhibition network, and a "midnight midinette ball." Despite how lighthearted this all may seem, the French state feared the revolutionary potential of the Syndicat de l'Habillement. The large number of Jewish members of the union meant that many speeches were given in Yiddish, eluding the state agents sent to infiltrate their meetings. ${ }^{71}$ The French state was particularly suspicious of the creation of an inter-syndical group made up of Russian and Polish Jews, some of whom were members of the Syndicat de l'Habillement, who they felt had "anarchistic leanings." 72 The secretary of the union, Claudine Lemoine, was put under special surveillance by the French secret police, who kept a close eye on "all her movements, her relationships, and her correspondence." During meetings union members would discuss increasing salaries, improving workplace hygiene, and women's role in syndicalism. ${ }^{74}$

But even with the gains made in 1917 and 1919, the situation of the midinettes in I92I was far from rosy. As Fernand Desprès wrote, "In exchange for 
their work they receive a salary that is incompatible with the cost of living." 75 According to the Syndicat de l'Habillement the working conditions for garment workers in the employment of Galeries Lafayette department store were awful, with thousands of women in the store's rue de Provence factory earning under 65 francs per week. ${ }^{76}$ One article asks, "How many of these unhappy midinettes are forced to eat their lunch in a bar with only a café crème and a sandwich!"77 It was no wonder, then, that Montmartre midinettes were predisposed to political activism.

\section{THE MIDINETTE AS POLITICAL ACTIVIST}

Farther south in the eighteenth arrondissement was a separate commercial hub that revolved around the vast Grands Magasins Dufayel department store. Here lived three fans who went much further than others and asked to meet the star in person. Figures 9 and Io reproduce their letter sent on April 20, 1921, two days before the serial's end.

Madame,

Please don't be indifferent toward a little trio of young girls who, being fervent admirers of their little "Ginette," would be very satisfied and happy if you could give them the great pleasure of visiting them in their workplace at the Palais de la Nouveauté, in the fashion department and where, at the same time, you will find delicious surprises!

With best wishes of friendship from three little madwomen [trois petites folles],

P.S. In the case that your visit is impossible, please be so kind as to write us a little note with some advice on how to get into the movies.

Finally, one way or another, don't forget three little madwomen.

Mlle Renée

Mlle Georgette

Mlle Simone

Return address:

Mlle Renée

Furs section

Palais de la Nouveauté

Magasins Dufayel

Paris $^{78}$ 
100

x Gavis le so Q avid 1) 1.

SHadane

indiflent the boely fuas de I) frenes filles quin étant de Peventer admiratrices de lour fictite "Gisettes seraient thet thatufaites, et heurestes si vout forwicy beur faine le grand filditir, de leur senche Sulite daust leur' Sravail an 'Palais de la Stouveaute', eayon de conliteric on fiar ha meme occiashor vout trouveriez de déliciendes Sufuises. folles, les meillewer amitiés

FIGURES 9-10. Letter to Sandra Milowanoff from the Grands Magasins Dufayel shopgirls, Paris, April 20, 1921. Cinémathèque française, Collection Jaune. (continued) 184

FEMINIST MEDIA HISTORIES FALL 2017 
Son cal on wotwe visite hrait infattible, verillez aroir l'óbliqeance, d'eivie un hetit wot, en domant qulfivel renteiguements, hour - Lata de cinbina.

Gufin d'une navieres ow d'sene autiv n'aubliz las les trait fietter folted,

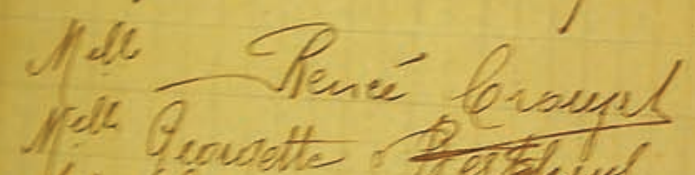

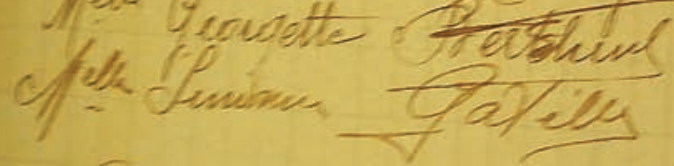

- Cdictle à rifrande -

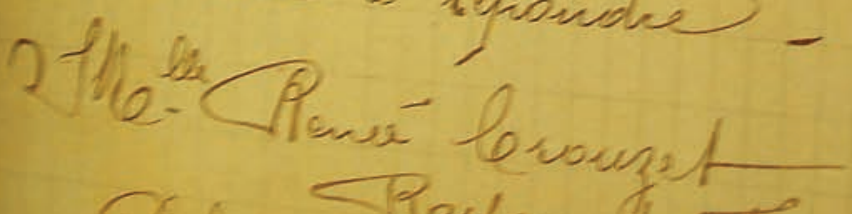

Rasfon de Fromined.

Golais de la Heorreaite.

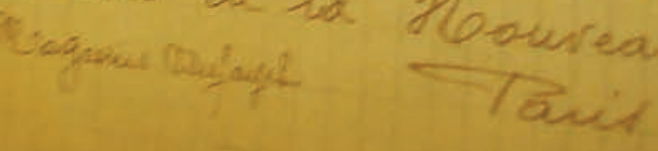

FIGURES 9-10. Letter to Sandra Milowanoff from the Grands Magasins Dufayel shopgirls, Paris, April 20, 1921. Cinémathèque française, Collection Jaune.

Fee | Les Midinettes Révolutionnaires

185 
The Grands Magasins Dufayel, where this group of Milowanoff fans worked, differed from other department stores in the capital because it was located in a working-class neighborhood, where commodities were priced to be more accessible for lower-income customers. ${ }^{79}$ This department store, where Renée Crouzet, Georgette Berthin, and Simone Gavily spent their long working days, was the first place in the eighteenth arrondissement where locals could see a film -at the Cinématographe Lumière, which opened inside the store in $1896 .^{80}$ The use of this 250-seat cinema was suspended during the war, and when it reopened as the Cinéma Dufayel, it was with a limited program. ${ }^{81}$ Since Les deux gamines was not programmed at this cinema, the shopgirls most likely took the short walk across the boulevard to catch the latest episode at the Barbès Palace, a I,200-seat first-run cinema on the boulevard Barbès.

Opened in 1914, the Barbès Palace was central to community life, not just as a distraction on days off, but also as a rallying place in times of need. Its location opposite the Grands Magasins Dufayel meant that workers like Renée, Georgette, and Simone could easily hurry across the boulevard for an evening film program. ${ }^{82}$ The leftist newspaper $L$ 'Humanité informs us that the cinema's proximity also made it the perfect gathering point for these same workers during labor disputes. ${ }^{83}$ In June 1919 Grands Magasins Dufayel workers held four separate meetings in the cinema palace. The Chambre syndicale des employés de la région parisienne called a meeting on June I following reports of general abusive behavior by store management and a specific case of unfair dismissal of a worker with twenty-two years of service to the store. ${ }^{84}$

At this meeting in the Barbès Palace, employees established a list of demands that were handed on to delegates from their union. It triggered the most important strike action by the employees' union in the interwar period. ${ }^{85}$ Two weeks later, on June i5, twelve hundred employees, male and female, from all departments of the Grands Magasins Dufayel voted unanimously in favor of the list of demands. ${ }^{86}$ They decided in the cinema that this list be passed on to the management without delay by the appointed delegation of the Chambre syndicale des employés de la région parisienne. ${ }^{87}$ Therefore, although the three salesgirls aligned themselves self-consciously with the overly passionate fan or "mad" midinette in their signing off as "les trois petites folles," their fan identity should not be misconstrued as altogether separate from union activism that took place in the same cinema in which they most likely worshipped their favorite star.

Addressing spatiality and micro-locality thus reveals how, in the 1920s, the act of going to the cinema could assume various significations depending on whether it took place in Montmartre or on a central boulevard in the entertainment 
district close to the Opera. Cinemas of the central entertainment district catered to a bourgeois clientele and wealthy foreigners. These cinemas were not used for trade union meetings, or fundraisers for local orphans, widows, and veterans, nor were they used as meeting places for Communist and Socialist Party members. Local cinemas in working-class neighborhoods had a much more socially homogenous public and were multifunctional community spaces for local people.

It is difficult, therefore, to reconcile Vailland's somnambulistic, fantasizing female spectator with the spectator-activist of interwar Montmartre. Rather than just obediently following the usher's light into another universe cut off from everyday realities, she would just as likely be using the cinema as a space of protest and collective action. It is worth pausing to consider one such cinema-centered protest during a summer that social historian Tyler Stovall describes as one of "widespread and dramatic working-class discontent in the capital." ${ }^{\text {"S }}$ Stovall indicates that the food crisis of 1919, much like the tenants' activist movement, "reflected very concrete concerns yet also contributed to a sense of revolutionary crisis in the year after the Armistice. In the right circumstances aggrieved housewives could bring down a government, and some Parisians saw the potential for just such a development in 1919."

On August I0, 1919, a vigilante group, the Montmartre League of Consumers (Ligue des consommateurs de Montmartre), organized a rally in the Cinéma Ornano after which one thousand women carried out a mini-revolution at the Ornano market just outside the theater. As a privately owned space, the cinema was outside of government control, and its location on the same boulevard as the market allowed the activists to tactically position themselves as a collective. Perhaps this was why the Montmartre League of Consumers was the first and the largest in the city. During the tactical meeting, M. Mugnier, president of the league, informed the audience of women of the going rate for various fruits, vegetables, meat, and dairy items so that they could boycott shopkeepers and market sellers who raised their prices above these levels. ${ }^{90}$ At the end of the meeting the audience cast a vote in favor of the measures taken by this week-old organization, measures that included "demanding that the government lower the farm gate price of foods and ... apply the death penalty to profiteers." ${ }^{\text {"11 }}$ After a general call for calm and nonviolence the local women left the cinema and flowed out into the boulevard Ornano, where they formed a price watch patrol (promenade de contrôle) of the market that ran the whole length of the boulevard.

"The parade of women, each with a string bag or basket on their arm, followed the league's inspectors, who in turn were escorted by the police. From this moment the market took on an unusual feel. The women surrounded a 
market woman who was selling her cabbages for thirty centimes apiece." After being told by the contrôleur that her cabbages were too expensive and that they should be no more than four pennies each, she simply changed the sign and said, "Go on, four pennies it is then! Who wants some?" At that point there was a rush on the reduced-price cabbages and women jostled and pushed through to buy them. ${ }^{92}$ The crowd then moved on to a butcher selling overpriced rabbit. The merchant was pressured to reduce his prices by seventy centimes per pound, which provoked women in the crowd who had already bought rabbit at the higher price from him earlier the same morning to demand the difference reimbursed. The merchant refused, and the police were forced to intervene to report the incident. After passing through the market and securing price cuts on cauliflowers, lettuces, potatoes, tomatoes, carrots, grapes, and plums, the women "were unable to hide their delight." The cinema Ornano meeting had instigated this "revolution at the Ornano market."

When the one thousand determined activist women filled the thousand-seat cinema that day, they appropriated the space for their specific needs. Much as the midinettes who had gone on strike to secure the semaine anglaise in 1917 , these working-class women saw no contradiction in using the very same space where many of them would have gone every week to catch the latest episode of a popular serial such as Les deux gamines, perhaps daydreaming of one day becoming a movie star like Sandra Milowanoff themselves, for purposes of forcing a change in their living conditions. For the cinemagoers of Montmartre, the local cinema was fully embedded in the social and spatial coordinates of working-class life-as much a part of their slice of the Parisian public sphere as their workplace.

\section{THE SOCIALLY EMBEDDED MOVIE FAN}

The Cinéma Ornano was part of the women's geography of Montmartre. Similar in their self-determination to fans of Sandra Milowanoff, these women joined together in cinemas as resistive consumers. The location of the Cinéma Ornano in northern Montmartre allowed for collective action away from the hustle and bustle of the market on the street outside. The local embeddedness of cinemas-that is, the spatial closeness of cinemas to the workplace-allowed for successful trade union actions against employers in several arrondissements, but it was particularly successful in Montmartre. Activists gathered to decide on how their behavior could help achieve positive results such as the lowering of market prices. In the same arrondissement female fans of Milowanoff took a different form of collective action by writing letters, a practice one could 
similarly read as a tactic of social mobility and a gesture toward revolutionary class reversal.

In a wider sense, local faubourg cinemas can be seen as functioning as a "commons" in which working-class men and women, wounded veterans, families threated by eviction, and housewives suffering from rising food prices carved out both space and time for leisure, rest, debate, protest, and collective decision-making. Popular cinemas thus became sites where Parisians seeking refuge from the traumas of war, the workplace, and economic difficulties blended working-class entertainment culture with social organization in a commonsense way. Interpreted in this light, the fan letters from Milowanoffs lowbrow fans show that women's relationship to cinema was far more complex than that communicated by the midinette stereotype. Their engagement with cinema in the years following the Great War shows diverse ways in which they were not just watching popular films, but also taking control of their own present and shaping their own futures.

Film history's absorption of the cinephile message of artistic legitimation means that the gendered and class-based discursive violence of early cinephiles has been largely overlooked. With the recent resurgence of scholarly interest in cinephilia, it is all the more necessary to complicate this dominant paradigm with the female geographies written on the streets of Paris by hitherto voiceless historical subjects. If we are to move beyond the gender- and class-based hierarchies of spectatorship and critique that emerged in film criticism during the interwar period and have continued to posit the reception of bourgeois male cinephiles as paradigmatic while ignoring the numerically superior spectator practices of female, working-class fans, then we must take into account the social and political context of cinemagoing in working-class neighborhoods of Paris. These cinemas were embedded in the concerns, worries, aspirations, and hopes of local people who participated in cinemas as spectators and star admirers, but also as spectator-activists, spectator-voters, and spectator-trade unionists. Alternative archival sources such as readers' letter columns, fan letters, and notices in the leftist press reveal cinemas to be meeting places for diverse political, social, and leisure activities, many of which were self-consciously opposed to the project of the cinephiles.

\footnotetext{
ANNIE FEe is a postdoctoral fellow in the Department of Media and Communication at the University of Oslo. Her work has appeared in Early Popular Visual Culture and is forthcoming in several journals and edited volumes. She is currently developing an interactive historical map of 1920s Parisian cinema culture and working on a book manuscript dealing with the class and gender politics at play in the emergence of cinephilia in interwar France.
} 


\section{NOTES}

I. André Breton, Nadja, trans. Richard Howard (New York: Grove, 1960), 37.

2. Louis Delluc, "The Crowd," in French Film Theory and Criticism: A History/ Anthology, vol. I, 1907-1939, ed. Richard Abel (Princeton NJ: Princeton University Press, 1998), 159-64.

3. For more on the provocative cinemagoing practices of André Breton and the Surrealists, see Jenny Lefcourt, "Aller au cinéma, aller au peuple," Revue d'histoire moderne et contemporaine 5I, no. 4 (2004): 98-II4.

4. Richard Abel, French Cinema: The First Wave, Igrs-Ig29 (Princeton, NJ: Princeton University Press, 1984), 279.

5. Jennifer Wild, The Parisian Avant-Garde in the Age of Cinema, 19oo-1923 (Oakland: University of California Press, 2015), I45; Tom Gunning, "The Cinema of Attraction: Early Film, Its Spectator and the Avant-Garde," Wide Angle 8, nos. 3/4 (1986): 63-70.

6. For more on the female movie fan in the United States see Diana Anselmo-Sequeira, "Screen-Struck: The Invention of the Movie Girl Fan," Cinema Journal 55, no. I (2015): I-28; Shelley Stamp, Movie-Struck Girls: Women and Motion Picture Culture after the Nickelodeon (Princeton, NJ: Princeton University Press, 2000). For more on the female movie fan in Great Britain, see Lisa Stead, Off to the Pictures: Women's Writing, Cinemagoing and Movie Culture in Interwar Britain (Edinburgh: Edinburgh University Press, 2016).

7. Pierre Henry, "Après l'écran," Ciné pour tous, February 24, I922, 5. All translations are my own unless otherwise noted.

8. Christophe Gauthier, La passion du cinéma: cinéphiles, ciné-clubs et salles spécialisées à Paris de 1920 à 1929 (Paris: AFRHC, 1999), 248.

9. Jean Epstein, "Le cinéma mystique," Cinéa, June I0, I921, I2.

Iо. Christian Metz, The Imaginary Signifier: Psychoanalysis and the Cinema (Bloomington: Indiana University Press, 1982), 96.

II. Patricia Tilburg, “Sa Coquetterie Tue La Faim': Garment Workers, Lunch Reform, and the Parisian Midinette, 1896-1933," French Historical Studies 38, no. 2 (2015): 282.

I2. For representations of the midinette in popular French song, see Anne Monjaret and Michela Nicolai, "La midinette en chansons: représentations masculines d'un idéal féminin populaire (1830-1939)," in Représentations: Le Genre à l’euvre, ed. Melody JanRé (Paris: L'Harmattan, 20I2), IOI-16.

13. Alfred de Musset, "Mademoiselle Mimi Pinson," in Contes (Paris: Charpentier, I854), 225-70. There were many film adaptations of de Musset's tale during the silent era, including Georges Monca's Mimi Pinson aime les roses blanches (1909), Georges Denola's Mimi Pinson (I911), Henri Adréani’s Mimi Trottin (1923), and Théo Bergerat's Mimi Pinson (1924).

I4. Octave Uzanne, The Modern Parisienne (London: William Heinemann, I9I2), 43.

I5. For more on Suzanne Grandais see Didier Blonde, "Pour Suzanne Grandais," I895, no. 66 (2012): II4-23.

I6. Iris, "Le Courrier des Amis," Cinémagazine, January 9, I925, 90.

17. M. J. K., "Nancy," Cinémagazine, April 17, 1925, I16; "Ciné-Revue," Mon Ciné, December 9, 1926, I2-13. 
I8. Geneviève Sellier, "Formes de cinéphilie au féminin dans les années i950: le courrier des lecteurs de Cinémonde," Studies in French Cinema I5, no. I (2015): 88.

19. Geneviève Sellier, "L'Expertise de la spectatrice ordinaire dans le courrier des lecteurs des magazines populaires: le cas de L'Ecran français," Studies in French Cinema ı, no. 3 (2010): 228 .

20. Ibid., 23 .

21. Pierre Eisenreich, "Les Âmes vagabondes / The Host," Positif, May 2013, 4I.

22. Eithne O'Neill, "Londres et l'écran contemporain: Ça ne vous mine pas d'habiter le ghetto?," Positif, December 2011, I05.

23. Yann Tobin, "Des siècles de cinéma," Positif, December 1993, 80.

24. Michel Sineux, "Gérard Depardieu: Jean-Paul Belmondo. Jane Birkin," Positif, August 1986, I23.

25. James Hay, "Piecing Together What Remains of the Cinematic City," in The Cinematic City, ed. David Clarke (London: Routledge, 1997), 2 IO.

26. "In fact, cinephile sociability and Parisian high society criss-cross narrowly, and one could even postulate that both set themselves apart within the geography of Parisian cinemas by separating themselves from the faubourgs." Gauthier, La passion du cinéma, 272.

27. Lettres d'admirateurs à Sandra Milowanoff, I921, Collection Jaune, CJi862-B235, Bibliothèque du Film, Cinémathèque française.

28. Jennifer M. Bean, "Introduction: Toward a Feminist Historiography of Early Cinema," in A Feminist Reader in Early Cinema, ed. Jennifer M. Bean and Diane Negra (Durham, NC: Duke University Press, 2002), 2-26; Antonia Lant, ed., The Red Velvet Seat: Women's Writings on the First Fifty Years of Cinema (London and New York: Verso, 2006); Stamp, Movie-Struck Girls.

29. "Entre Nous," Ciné pour tous, May 22, 1920, 6; Iris, "Courrier des 'Amis du Cinéma," Cinémagazine, June 17, 1921, 30.

30. "Entre Nous," Ciné pour tous, October 8, I921, I2; "Entre Nous," Ciné pour tous, May 5, I922, I6.

31. "Le premier mai. Les réunions et meetings. Le Parti," Le Populaire, May I, 1919, 4.

32. These include Les deux gamines, L'Orpheline (1921), Parisette (1922), Le fils du flibustier (1922), Le gamin de Paris (1923), and L'Orphelin de Paris (1924).

33. Cast members also included Violette Jyl, Édouard Mathé, Bout de Zan, Blanche Montel, Fernand Herrmann, and Gaston Michel.

34. Written installments of each episode adapted by Paul Cartoux appeared daily in the newspaper L'Intransigeant beginning on January 22, 1921. Each new episode appeared in print six days before being released on Parisian screens. For serial tie-ins and female fandom in the US context see Stamp, Movie-Struck Girls, 102-53.

35. Parisot quoted in Jean-Louis Croze, "A propos du Penseur," Comoedia, July I6, I920, 3. Regarding the location see "Programmes du 28 Janvier au 3 Février," Le Journal du Ciné-Club, January 28, 1921, 8. Child actress Mano lived in the same neighborhood as the Idéal Cinéma at I, Cité des bains (now named Villa Dancourt). See Iris, "Courrier des 'Amis du Cinéma," Cinémagazine, July 8, I92 I, 30.

36. Jean Frick, Mon Ciné, April I3, 1922, 5. 
37. Jean Mitry, "M. Marcel L'Herbier," Le Théâtre et Comoedia illustré, April I5, I924, I-2.

38. Marguerite Bourcet, "L’Écran, reflet de la vie," Études, July 20, I936, I85.

39. Ibid., 174; Maurice Bardèche and Robert Brasillach, Histoire du cinéma (Paris: Louis Bellenand et fils, 1935).

40. Louis Delluc, Le cinéma au quotidien, vol. 2, ed. Pierre Lherminier (Paris: Cinémathèque française, 1990), 92.

4I. Louis Delluc, "Notes pour moi," Le Film, April 29, 1918, 29-31, 30; Louis Delluc, "Petit guide pour les amateurs," Le Film, August 26, 1918, I6-18, I6.

42. Louis Delluc, "Quelques films français," Cinéa, September 9, I921, 6.

43. David Bordwell, On the History of Film Style (Cambridge, MA: Harvard University Press, 1997), 38.

44. L'Oeil-de-Chat, "Réponses à quelques lettres," Cinéa, May 27, I921, 2.

45. Pierre Veber, "Les présentations par Pierre Veber: Les deux gamines," Scénario, November 15, 1920, 490. The Boulevard du Crime was the nineteenth-century nickname for the Boulevard du Temple due to the theaters showing crime melodramas to raucous publics.

46. Pierre Henry, "Surimpressions," Ciné pour tous, May 5, 1922, 7.

47. Pierre Henry, "Personnages noir et blanc," Ciné pour tous, June 17, I921, 8.

48. "If The Three Musketeers, in France, had been made by Louis Feuillade, it is easy to guess what the cast would look like: Mme Bonacieux (S. Milowanoff), Planchet (Biscot), d'Artagnan (René Clair), Athos (F. Herrmann)... . If the same piece had been proposed to Marcel L'Herbier, we would have had: D'Artagnan (Jaque-Catelain), Milady (Eve Francis), Mme Bonacieux (Marcelle Pradot). .." "Surimpressions," Ciné pour tous, March IO, $1922,4$.

49. Roger Vailland, “La spectatrice idéale," L'Éuropéen, November 27, 1929, 8.

50. Lant, The Red Velvet Seat, 2.

5I. For a comprehensive study of readers' letter columns in the film press see Emilie Charpentier, "Spectateurs, vous avez la parole!: le courrier des lecteurs dans Cinémagazine et Mon Ciné" (master's thesis, Université Paris I Panthéon-Sorbonne, 2003).

52. Guillaume Danvers, "Nos grandes vedettes: Sandra Milowanoff," Cinémagazine, October 21, I921, 5-7.

53. Iris, "Petite Correspondance," Cinémagazine, March 4, I921, 9; "Entre Nous," Ciné pour tous, February II, I92I, II.

54. Six cinemas began screening the serial in its first week, and three cinemas in the second week. See "Liste des cinémas où doivent passer Les deux gamines," L'Intransigeant, January 28, 1921, 3.

55. There were 208 cinemas in Paris in 1922. The eighteenth and twentieth were the arrondissements with the most cinemas, with twenty-one each. In second place was the tenth with sixteen cinemas. "Les cinémas," L'Aurore, March I8, I922, 2.

56. In May 1921, according to Cinéa programs, thirteen out of fifty-eight listed cinemas had such attractions, a third of them in the eighteenth arrondissement.

57. Jules Galmiche, "Les étrangers dans l'agglomération parisienne d'après le recensement de 1921," Bulletin de la statistique générale de la France 9, no. 3 (1922): 306. 
58. Edward Jefford and John George Bartholomew, Paris pour tous (Paris: J. M. Dent, I919), I0-II. One hectare is ten thousand square meters.

59. Ibid., I2-13.

6o. Antoine Prost, "La rue de la Goutte-d'Or et la rue Polonceau entre les deux guerres," Le Mouvement social, no. I82 (January 1998): 18.

6I. Fernand Desprès, "La vie douloureuse des travailleurs de l'habillement," L'Humanité, November 26, I921, I.

62. The reference is to Clifford Geertz, "Thick Description: Toward an Interpretive Theory of Culture," in The Interpretation of Cultures (New York: Basic, 1973), 3-30.

63. The reference is to Michel de Certeau, The Practice of Everyday Life (Berkeley: University of California Press, 1984), 34.

64. The four administrative quartiers of the eighteenth arrondissement are: Quartier de la Chapelle, Quartier de la Goutte-d'Or, Quartier des Grandes-Carrières, and Quartier de Clignancourt.

65. Jean-Jacques Meusy, Paris-Palaces, ou le temps des cinémas (1894-1918) (Paris: CNRS Éditions, AFRHC, 2002), 36r. It was owned and operated by former mechanics Léonard Meillat and André Hanhart.

66. Collection Jaune, CJ1862-B235, letter 23, Bibliothèque du Film, Cinémathèque française.

67. Nancy L. Green, Ready-to-Wear and Ready-to-Work: A Century of Industry and Immigrants in Paris and New York (Durham, NC: Duke University Press, 1997), 84. For a useful analysis of the 1917 midinette strike in English, see Maude Bass-Kreuger, "From the 'Union Parfaite' to the 'Union Brisée': The French Couture Industry and the Midinettes during the Great War," Costume 47, no. I (2013): 28-44.

68. Claude Didry, "Les Midinettes, avant-garde oubliée du prolétariat," L'Homme et La Société, nos. 189/190 (2013): $8 \mathrm{I}$.

69. In 1914, the Syndicat de l'Habillement made a film in collaboration with the shortlived Cinéma du Peuple film cooperative in protest of the exploitative conditions of seamstresses. The film, directed by Raphaël Clamour, was called The Miseries of the Needle (Les misères de l'aiguille) and starred Musidora. See Tangui Perron, "Le contrepoison est entre vos mains, camarades' C. G. T. et cinéma au début du siècle," Le Mouvement Social, no. 172 (July 1995): 2I-37.

70. Annie Fee, “Gaumont Offers 'La Russie Rouge' and 'All Paris Takes Sides': Working-Class Activism in Paris Cinemas, 1921-1922," Early Popular Visual Culture 12, no. 2 (April 2014): 254-57; "Fêtes et conférences," L'Humanité, December 24, I921, 4.

7 I. Unsigned letter in folder "Notes russes" on the subject of "Syndicat de l'Habillement Meeting.” Archives nationales, Police générale, F7 13490. P. 5. 400. U. Letter dated September 28, I92I.

72. Unsigned letter in folder "Notes russes" on the subject of "A Jewish Communist Group in Paris." Archives nationales, Police générale, F7 13490. P. 5. 410. U. Letter dated October 4, I92I.

73. Unsigned letter in folder "Notes russes" on the subject of "French Revolutionaries in Russia." Archives nationales, Police générale, F7 13490. P. 5374 . U. Letter dated September 22, I92I. 
74. "Dans l'Habillement," L'Humanité, October 6, I921, 3.

75. Desprès, "La vie douloureuse des travailleurs de l'habillement," I.

76. In I92I a modest meal at a workers' café cost between three and four francs, and the cheapest cinema ticket was around I fr. 20. See Jacques Valdour, La vie ouvrière. Ouvriers parisiens d'après-guerre. Observations vécues (Paris: Arthur Rousseau; Lille: René Giard, 1921), 12, 69. In December 1920, one franc was the equivalent of one US dollar. Maurice Dekobra, "La vie est-elle chère au pays des dollars?," Le Journal, December 23 , I920, I.

77. Syndicat de l'Habillement, “À la société parisienne de confection," L'Humanité, October 23, I921, 5 .

78. Collection Jaune, CJ1862-B235, letter ı00, Bibliothèque du Film, Cinémathèque française.

79. Brian Wemp, "Social Space, Technology, and Consumer Culture at the Grands Magasins Dufayel," Historical Reflections 37, no. I (2011): I-I7.

80. Meusy, Paris-Palaces, ou le temps des cinémas (1894-1918), 35-37.

8I. Ibid., $45 \mathrm{I}-52$.

82. Ibid., 302.

83. It was not just the Magasins Dufayel employees who met in cinemas for union activities. The employees of the Printemps department store met at the Palais de la Mutualité cinema during a strike action the same month: "L'agitation ouvrière: La Grève du Printemps," L'Humanité, June 2, 1919, 4; "La Grève du Printemps," L'Humanité, June 3, 1919, I.

84. "L'Agitation ouvrière: Aux Magasins Dufayel," L'Humanité, May 31, I919, 4.

85. Annie Fourcaut, Fermmes à l'usine: ouvrières et surintendantes dans les entreprises françaises de l'entre-deux-guerres (Paris: F. Maspero, 1982), 218.

86. "Les syndicats: Employés de la région parisienne (Section Dufayel)," Le Populaire, June $18,1919,2$.

87. Ibid.; "L'Agitation ouvrière: Aux Magasins Dufayel," L'Humanité, June 17, 1919, 4.

88. Tyler Stovall, Paris and the Spirit of IgIg: Consumer Struggles, Transnationalism, and Revolution (Cambridge, England, and New York: Cambridge University Press, 20I2), 212.

89. Ibid.

90. Armand Villette, "Une matinée avec la ligue de Montmartre," Le Gaulois, August II, I919, I.

91. Ibid.

92. Ibid.

93. Ibid. 